\title{
Oikeion and justice in Plato's Republic
}

\author{
CHARlotTe MURGier \\ Université Paris Est, Créteil \\ charlotte.murgier@u-pec.fr
}

Recibido: 27/06/2017 - Aceptado: 25/09/2017
DOI: https://doi.org/10.20318/fons.2017.3859

\begin{abstract}
This paper aims at investigating the notion of oikeĩov (one's own) in Plato's Republic, by assessing what it specifically adds to the Platonic account of justice. Although the investigation is mostly devoted to analyzing the relevant passages of Book IV where the definition of justice as oikeiopragia is elaborated, it starts with the first occurrences of the term oikeĩov in the former books of the Republic, showing how the notion is introduced to counter Trasymachus' challenge and then philosophically refined in order to make sense of the Platonic claim that justice does not harm but rather favors one's own good.
\end{abstract}

Keywords: justice, Trasymachus, oikeion (one’s own), good

According to Aristoxenus of Tarentum, who heard this anecdote from Aristotle himself, Plato's lecture on the Good caused surprise, incomprehension, even indignation among the audience ${ }^{1}$. Instead of the expected discussion about the traditional human goods like wealth, health, strength, etc., they were treated to a lecture on mathematical notions ending with the seemingly far-fetched conclusion that the Good is the One. This anecdote, whether true or false, would hardly surprise Plato's readers who might now and then experience the same perplexity as his audience did centuries ago. They may be puzzled by some of the views endorsed by his main character and spokesman Socrates, who is never afraid of challenging common sense. Many of these unexpected views can be found in the Republic, and among them is the account of justice. Although it may be less spectacular than the above proposition, the description of justice as the state in which a city or a soul is doing one's own is a feature difficult to understand and to accommodate with everyday intuition.

\footnotetext{
${ }^{1}$ See Aristoxenus, Elementa Harmonica II 20, 16 ff., in Ross 1955, p. 111.
}

П НГН / F O N S II (2017), 65-85

ISSN 2445-2297 www.uc3m.es/pege
Ch. Murgier, Oikeion and justice in Plato's Republic DOI https://doi.org/10.20318/fons.2017.3859 
The puzzling description of the just person as «doing his own» seems to baffle Socrates' interlocutors as well as Plato's commentators. This is not only true for modern readers ${ }^{2}$, but also for antiquity. Indeed, Aristotle's reaction does not fail to counteract Plato's account by going back to the characterization of justice as á $\lambda \lambda \lambda_{\text {ótpov }}$

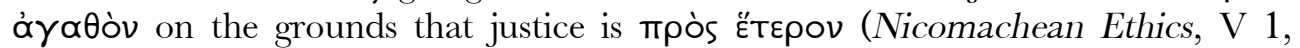
1130a3-4). Although he grants Plato that justice is the complete excellence, he is careful to add the crucial qualification, holding for general as well as particular justice ${ }^{3}$, that justice is concerned with others, advocating thereby a view presumably more akin to everyday intuition. The most obvious feature of justice, namely that it concerns and regulates our interactions with other persons, seems to vanish in the Platonic formula, or at least to be implied only in a negative or privative way, that of not encroaching upon their goods or rights. Plato's deflationist account might then appear to be disappointingly far below common expectations about the meaning of justice. Even Cephalus' or Polemarchus' suggestions seem to say more about the interpersonal dimension of justice: their respective accounts, «to speak the truth and repay what one has borrowed» (331d2) and «to give to each what is owed to him» (331e4) then amended into «treating friends well and enemies badly» (332d6) do involve the relationship to another ${ }^{4}$. The somehow paradoxical gesture of turning to one's own in order to account for justice, the relational virtue par excellence, then, calls and deserves attention. In this paper I would like to indirectly investigate this account of justice by calling attention to the contribution to it of the oikenov, usually translated as «one's own». Indeed, my assumption is that this notion, though apparently loose and trivial and often taken as a synonym for the possessive, should not be overlooked 5 . It enters not only into the characterization of justice as oikeı mpa yía but it also plays a significant part in the whole frame of the Republic.

This notion, first, is meant to respond to the polemical challenge of Thrasymachus, soon taken over by Plato's two brothers. Despite some nuances, the bulk of the discourse remains basically the same: justice is not worth choosing for its own sake, rather something that everyone who can afford it would and should dispense with. Either taken as the lesser evil necessary for anyone engaged in social life or indicted as

\footnotetext{
${ }^{2}$ Some of them pinpoint a gap, not to say a flaw, in the articulation between the social and psychological accounts of justice (see VlaSTOS 1968). Some confess - or intend to defend Plato's theory against - a difficulty in relating this conception of justice to the commonly held view according to which justice is concerned with the good of others and so demands to set aside one's own interest for the sake of theirs (see WATERLOW 1972).

${ }^{3}$ See NE V 2, 1130b1, V 6, 1134b5.

${ }^{4}$ Here and after, I cite Reeve's translation of the Republic (Reeve 2004), occasionally slightly modified.

${ }^{5}$ Few scholars pay attention to the notion. An exception is HeLmer 2010, pp. 258-260.
} 
the deceptive value thanks to which the stronger take advantage of the people coward or credulous enough to comply with it, justice would be deprived of any intrinsic value. The continuity between Thrasymachus' charge and the two brothers' challenge is supported by the quick summary of the case against justice at 392b1-3, which brings together the attacks of the former and the suspicions of the latter ${ }^{6}$ :

«They [i.e. poets and prose writers] say that many unjust people are happy and many just ones wretched, that doing injustice is profitable if it escapes detection, and that justice is another's good but one's own loss».

For the purpose of this paper, I will focus on Thrasymachus' charge precisely because he points out a divorce between justice and one's own (oikeĩov) interests or goods. When Socrates endeavors to meet his challenge and to rehabilitate justice, his use of the term oikeĩov aims then at denying such a divorce and at grounding some of the major ethical concepts at play in the Republic, namely justice and virtue, into the deepest interests of the human being. By doing so, the notion functions as a kind of binder between them.

My main purpose is therefore to identify what the notion of oikeĩov specifically adds to the Platonic account of justice and thereby to that of the (human) good. This investigation will be mostly devoted to analyzing the relevant passages of Book IV where the definition of justice is elaborated. This will first require placing the concept into a wider context, by pointing out some of its meaningful occurrences in the previous books. This review does not pretend to be exhaustive: it will limit itself to those passages with a specific and philosophically significant argument and leave aside the (many) occurrences of ordinary meaning where oikeĩov and its derivatives simply refer to relatives 7 . It intends to highlight this first remarkable feature of the oikeĩov, namely that the notion marks the long journey of the Republic by occurring at turning points and key passages. Its initial mention appears at the very beginning, in Book I presenting the twofold challenge about justice: what is justice (a) and is justice more beneficial, i.e. does it make one happier, than injustice (b)? Oikẽov resurfaces in the middle (Book IV) when the question of the definition is resolved; it makes a final appearance in Book X, although the initial concern about the comparative value of a just and an unjust life has been ultimately and definitely assuaged.

Given that the notion occurs in the book at specific and strategic places, I would like to review some of the occurrences I take as meaningful in order to bring out how

${ }^{6}$ The underlying psychological assumptions are also similar, as pointed out by COOPER 2004, pp. 248-249. See also Burnyeat's cases for taking Glaucon and Adimantus as the heirs of their «dialectical» father, Thrasymachus (BURNYEAT 2004).

${ }^{7}$ See, e.g., 329b1, d3. 
the notion works as a thread in the vast frame of the Republic and to relate it to the overall challenge of the work.

My first point (1) consists in recalling and unfolding Thrasymachus' challenge that lays out the main stake of the inquiry. In this challenge the notion of one's own plays a significant role for it is precisely what is being wronged by justice. My second step (2) concerns Socrates' first and tentative reply at the end of Book I that brings in the

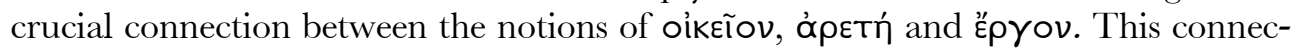
tion underlies the final account of justice in the city and in the soul, elaborated in Book IV - to which my ultimate point (3) is devoted. I will focus on the concept of

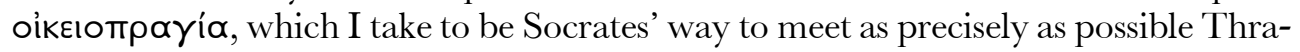
symachus' challenge. This notion is meant to characterize justice and to ground this virtue in the interests and the genuine nature of the agent in order to bridge the gap opened by Thrasymachus between one's own and justice.

\section{The oikeĩov in the debate on justice (Book I)}

The first philosophically significant reference is to be found in Thrasymachus' speech that sets the challenge of the Republic. He breaks into the discussion in order to react against the paradoxical Socratic stance resulting from Polemarchus' examination, namely that justice can never harm anyone, even one's enemies. Thrasymachus counteracts this paradox by bringing in another one, which is meant to demystify the alleged value of justice. His first claim is that justice is nothing other than the advantage of the stronger (338c1). Indeed, he takes justice to be embodied into laws that are made up by the rulers and therefore subject to change according to the interests of the party in power. Forced to vindicate his dismissal of justice against Socrates' dialectical moves, Thrasymachus introduces then the notion of oikeĩov in order to elaborate its initial claim. He articulates his case against justice in two related points that bring out the problematical - for antagonistic - relationship between justice and one's own. The first point consists in pointing out the negative impact of justice on the life of the person practicing it. The second point, following from that and spelled out a bit later on (348c5-349a1), is that given the harmful effects of justice on one's life, it ought not to be considered as an excellence (ápєtń), i.e. something valuable for its possessor.

Thrasymachus' main point is that justice is some alien good, rather than one's own. As a result, far from promoting one's interest, the cost of justice is very likely to be paid by the self. This contrasts with the view advocated by Socrates during his earlier discussion with Polemarchus, according to which justice, being a virtue, can never harm anyone (335d11-2). For a virtue, i.e. something good, cannot make worse the being to which it applies (335b-e). Thrasymachus supports the very opposite: justice does harm, but not the person whom it addresses, the enemy one would like to hurt, 
according to the commonsense morality advocated by Polemarchus ${ }^{8}$. Rather, justice according to Thrasymachus harms the very person who displays it. The overall

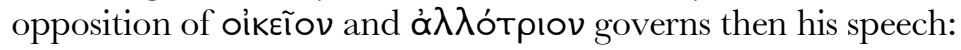

«You do not realize that justice and what is just are really the good of another [ád $\lambda \lambda$ ótpiov áy $\alpha \theta \dot{v} v]$, what is advantageous for the stronger and the ruler, and a harm that is all his own for

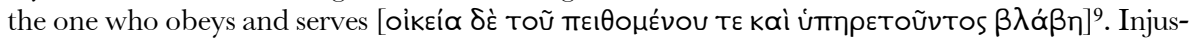
tice is the opposite, it rules those simpleminded - for that is what they really are - and just people, and the ones it rules do what is advantageous for the other who is stronger, and they make the one they serve happy, but they do not make themselves the least bit happy» (343c3-d1).

Justice, at least when practiced by ordinary people, those who are not in position to rule, is not only some quality directed to the good of another, as people usually believe; it is also so entirely committed to the good of others that it turns out to be at one's own expense. This point is further illustrated by the various contexts and manners where the just person harms his interest (343d3).

«Finally, when each of them holds political office, a just person - even if he is not penalized

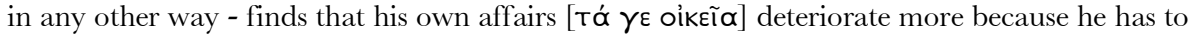
neglect them, that he gains no advantage from the public purse because of his justice, and that he is hated by his relatives [Toĩs oikeíoss] and acquaintances because he is unwilling to do them an unjust favor. The opposite is true of an unjust man in every respect» (343e1-7).

Practicing justice doubly harms the agent's own interest - what is literally oikeĩov to him. The first aspect of the incompatibility between justice and one's own is material. Justice causes him to neglect his own business (тó oỉkeĩa). For, when devoting himself to the commitments of public office, he cannot help but somewhat abandon his own business, since he can neither take care of it full time nor compensate such a sacrifice by taking advantage of public funds. Compounding this negative effect is the fact that the agent is also losing out in social and moral goods, inasmuch as his friends and relatives, literally his oíkeĩoı, tend to distance themselves when they realize that they won't get anything from him and his public office, as they were expecting to. The two occurrences of oikeĩov in these lines hint at the original and ordinary meaning of the term: etymologically it refers to the household (oikía) involving all those

8 The latter is likewise illustrated by Meno's first account of virtue at 71e2-5: «it is easy to say that a man's virtue consists of being able to manage public affairs and in doing so, to benefit his friends and harm his enemies and to be careful that no harm comes to himself» (transl. Grube in COOPER 1997). For further evidence in Greek philosophy and literature, see also BLUNDELL 1991, esp. chapter 2, pp. 26-59.

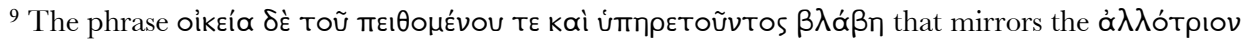

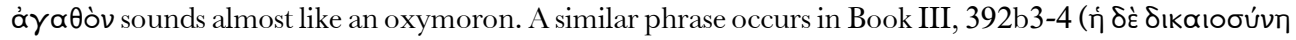

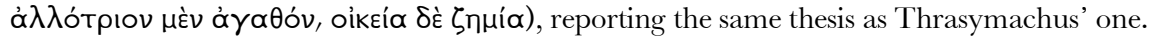


who live in the same house, to whom the subject is linked through blood, moral and affective ties. The result of justice is that the just man will lose out on both material

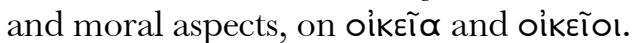

The effect here ascribed to just behavior contrasts with the view previously endorsed by Polemarchus on the behalf of Simonides, both advocating a common morality that Thrasymachus rejects. Justice was supposed to benefit one's friends (332a10f.). Thrasymachus' argument intends to prove that the just man will not be able to help his friends, contrary to what would be expected of him. Unsurprisingly then, he is likely, not to say he deserves, to lose his friends ${ }^{10}$. The material and moral (or affective) loss due to justice seriously impairs his chances to be happy, as pointed out at 343c8, insofar as wealth and friends are commonly held to be the best way to secure oneself from the reversals of fortune ${ }^{11}$. Justice is thus an alien good, i.e. it is not a good at all for those practicing it. Indeed, it deprives them of every layer of what is their own and what they would and should care about: wealth, honors and social consideration, and, ultimately, friendship and respect from their relatives, the genuine oikeĩoı. According to Thrasymachus, justice, though hypocritically praised by a commonsense morality, is actually a process of deep alienation. It turns out to be the sign of the weakness of simpleminded persons $(343 \mathrm{c} 6,348 \mathrm{c} 12)$ that enhances their helplessness by making them unable to secure any kind of good.

In a nutshell, the main and most remarkable effect of justice is to separate from his own anyone weak enough to practice it. Therefore, it is the contrary of any kind of capacity, and the opposite of excellence ('́pєtŕ) and wisdom (бофía), as Thrasymachus will argue at 348e1-3, consistent with his first account of the effects of justice. This twofold alienation, depriving the just person of the things and the beings close to him, contrasts indeed plainly with the effects that are to be expected from wisdom (бoфía). Let us turn briefly for example to the account of the wisdom originating friendship in the Lysis $(210 \mathrm{a}-\mathrm{d})$. Knowledge is precisely able to make oikeĩov what is otherwise experienced as alien (210c3): for the wise (бoфós), things become his own (210b5-6) insofar as he is the only one able to make the most of them, and

${ }^{10} \mathrm{~A}$ somehow similar process is described in Book VIII with the coming-to-be of the timocratic man, whose mother is complaining and blaming his father for not committing himself enough to public life.

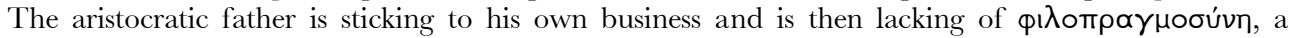

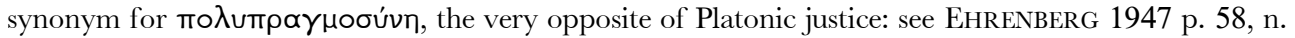
35. As a result, he is facing the reprobation of women and house-slaves: «those who do their own work

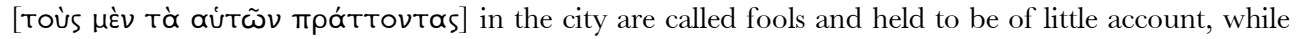
those who do not are honoured and praised» (550a2-4). The two reproaches of Thrasymachus and of the bitter wife meet in that being just - either according to the Platonic concept, still embodied by the aristocratic man, or in the common view indicted by Thrasymachus - causes failure in public and private life.

${ }^{11}$ See for instance the endoxa about friendship in Aristotle's Nicomachean Ethics VIII 1, 1155a10 and IX 9, 1169b9: a friend is the greatest of the external goods. 
the same holds for the persons since everyone is longing for the company of the wise person, expecting some benefit (210c7). Contrasted with this little protreptical discussion qualifying wisdom as the capacity for appropriation, Thrasymachus' argument leads to the conclusion that justice has nothing in common with the wisdom sketched out above and proves to be anything but a capacity. Instead of making anybody and anything appropriate (oikeĩov) to its bearer, it ends up in alienation in the proper sense of the term: just persons work for unjust men and serve them as their slaves. This contrasts once again with knowledge that bestows on its possessor unlimited freedom for any undertaking (Lysis, 210b4). It is injustice, according to Thrasymachus, that makes one «stronger, freer and more masterful» (344c4-6).

This apparently irreducible gap between what is just and what is one's own gives the impulse to the one-night inquiry in which Socrates has to show that being just can be at one's advantage and can promote one's happiness. The reconciliation between oikeĩov and justice, which occurs in Book IV with the characterization of justice as

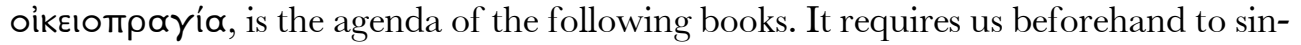
gle out what is genuinely oikeñov, i.e. to clarify what the oikeñov actually means.

\section{Oikeĩov and virtue in the function argument (Book I)}

Before turning to Book IV, let us consider the last significant mention of oikeĩov in Book I. It occurs in the last piece of Thrasymachus' refutation by Socrates, the Épyov/function argument. This argument has raised a great deal of discussion and suspicion among scholars but my point here is not to assess its relevance or coherence, but rather to call attention to the occurrences of oikeĩov within it. It takes justice to be a virtue and by doing so, it marks the first step towards an internalization of the concept of justice, which makes it not only the notion describing the rules that regulate the social interactions and interpersonal exchanges, but a property belonging to the soul ${ }^{12}$. In order to show that justice, as the virtue of the soul, will make its possessor happy, Socrates' strategy consists in defining virtue through the notion of 'eprov. The latter is characterized as follows: to any being, a proper function ("丷p yov) is attached, and this function qualifies him as the only or the most capable of performing this given activity. The correct performance of this task is what we call virtue or excellence ('̊рєтท́) and this account holds for any given being, including the soul. From the fact that the soul is endowed with a function - which, among other things, consists in living (something no other can accomplish) - follows that its related virtue or excellence must consist in living well. Socrates is then in a position to claim that justice, as the virtue

\footnotetext{
${ }^{12}$ HAVELOCK 1978 points out this progressive change of reference, from the social meaning of justice as the rule of reciprocity, which is still governing Cephalus' speech, to a moral quality that «can be possessed independently of one's relationship to another» (p. 311).
} 
of the soul - what Thrasymachus was finally forced to grant at $348 \mathrm{c}-350 \mathrm{~d}^{13}$ - is what makes us live well, i.e. be happy.

Now, if we turn to the meaning of oikeĩov in the function argument, we notice that each of the three occurrences of the adjective oikeiov at 353c1, 353c6, and $353 \mathrm{e} 2^{14}$ modifies the substantive ápetŕ. This modification does require an explanation. For what does it add to the notion of virtue that the latter does not already contain? If the virtue of any given being consists in the correct performance of his épyov, and if the latter is nothing other than that for which he is the only one or the best qualified - in other words, his own function - speaking of oíkeía ápetń sounds slightly redundant. What would be a virtue that would not be proper to its bearer?

One could simply take it that oikeĩov works here as a substitute for the possessive and does not convey any peculiar meaning. But even if it were the case, this does not entirely account for the redundancy ${ }^{15}$. This may rather intend to call attention to the fact that virtue does belong to and benefit its «practitioner». The emphasis makes sense if we keep in mind the target of the argument, namely Thrasymachus who made a case for the opposite view that the virtue of justice is alien to its possessor. Furthermore, adding oikeĩov to the notion of ápєтń makes it clear that the concept of virtue or excellence does not only apply to human or even living beings but that it extends to any possible being as soon as the latter is endowed with a function: an eye, a horse, etc. ${ }^{16}$ This prepares the ground for the idea that the soul as such has a virtue, which is a much more specific claim than the ordinary assertion that, for instance, human beings have virtue. This specific claim calls for a determination of such an excellence a task that will not be achieved until the end of Book IV where the composite nature of the soul is elucidated. By introducing the notion of oikeĩov, Socrates strengthens the intrinsic correlation between one's épyov and one's specific ópetŕ. Each of the

${ }^{13}$ Justice is also qualified as the «human virtue» without further discussion by Polemarchus at 335c4.

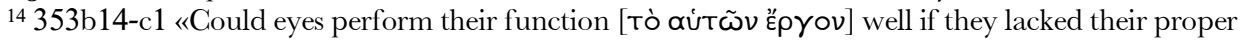

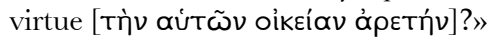

353c6-7 «I am not now asking about that, but about whether it is by means of their own proper

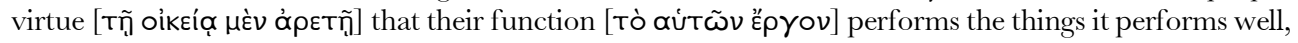
and by means of the vice badly».

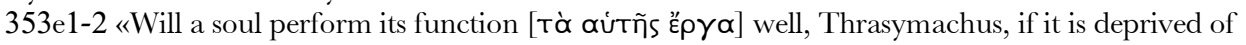
its own virtue [Tñs oikeías á $\rho \in t \tilde{s}$ ], or is that impossible?»

${ }^{15}$ See e.g. 353c1 where both the adjective and the genitive of possession are present: $\mu \eta \dot{~ E ́ X o v T \alpha ~ T i ̀ v ~}$

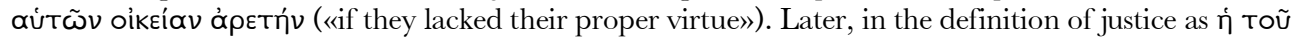

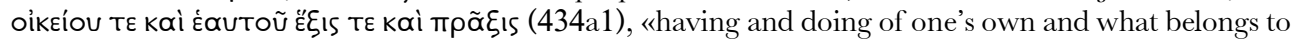
one», the oikeĩov and the genitive also appear as non-redundant.

16 The universal extension of the concept is made explicit in a reminder of the ápetŕ definition in Book X, 601d4-6: «Then aren't the virtue, goodness, and correctness of each manufactured item, living creature, and activity related to nothing but the use for which each is made or naturally developed?» 
three occurrences connects the proper excellence (oikeía ápetí) with the performance of the related function ("́pyov). An excellence is the correlative of a function, enables and expresses its fullest display. This argument results in significantly building the notion of virtue into the very nature of its «bearer» or possessor. For the virtue proper to any given being is related to the activity that makes it different from anything else. Indeed, everything else would be unable to perform the same activity (as) satisfactorily.

A virtue, according to this philosophical and promising definition ${ }^{17}$, belongs to a given being because it exhibits the best achievement of the very activity that defines it. Therefore, speaking of oikzía ápeтń points to the fact that virtue has to do with the genuine essence of the being in question and is specified by its very nature. The Épyov argument conveys the idea that for each human being virtue ought to be found in what he is genuinely. In so doing, it anticipates a view that the following books are about to provide with some more concrete content by introducing the class division according to natural abilities. The very end of the Republic will also echo this connection between virtue and nature, in a passage that shares with the present one a relatively abstract and ontological character. The proof of the immortality of the soul (608d-611d) will indeed rely upon what an oíkeĩov kakóv means for any given being. This evil is also qualified as oúmpuтov (609a3), that is, grounded in the very nature of the being in question. Socrates takes it that the proper evil is the one, if any, that is able to corrupt and to ruin the being it belongs to $(609 \mathrm{a} 8-\mathrm{b} 2)$. The challenge of the proof is then to find an item that cannot be destroyed by its proper evil, so as to make sure that it can resist any other corruption (609b4-6). Socrates turns then to the specific case of the soul and examines the effect on it of its proper evil, injustice: this obviously does not cause the destruction of its bearer for nobody dies, at least directly, from being unjust. He draws then the conclusion that the soul, whose proper evil is not likely to destroy it, cannot be ruined by anything else either and is then immortal. Similarly to the épyov argument, this ultimate proof relies upon the connection between the oikeĩov and the nature of the related being.

At the end of Thraysmachus' refutation, the link between oikeĩov and justice has been established through the broader notion of virtue, but it remains too superficial and tenuous to be really suitable. The function argument relies on a general concept of ápєtń that could apply to any other excellence, e.g. wisdom, temperance, courage, all of them being equally qualified to be virtues of the soul. It is therefore too loose to

${ }^{17}$ The ergon argument and its link to virtue will be famously taken up by Aristotle in Nicomachean Ethics I 7; in II 6, 1106a15-22 he gives the same account of virtue as the passage of the Republic, with the very same examples (eyes, horse). 
meet Thrasymachus' specific challenge focused on justice and its alleged value. Socrates has to show what entitles him to assimilate justice and virtue, instead of taking it for granted ${ }^{18}$. The ultimate account of justice in Book IV will articulate it as the virtue of the whole that encompasses and presupposes the others and will achieve such a result. However summary it may be, this very last argument of Book I is nonetheless decisive: it brings out the conceptual connection between the notions of oikeĩov,

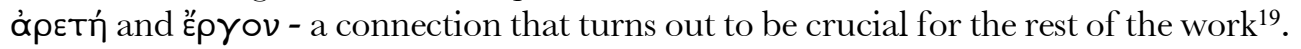
Indeed, what comes next draws upon this first step, unfolding the political and psychological implications of the ontological connection between these concepts. In Book II, the account of Épyov will receive further elaboration with the introduction of the principle of specialization within the city. The basis of the social organization relies implicitly upon what an épyov is, namely the work or activity that can be best or only achieved by someone or something.

The next steps will fill in this account by grounding the assigned function in one's distinctive natural abilities revealed by the selective education process. Finding one's function and keeping to it ultimately amounts to finding out what kind of person one is, one's place within the three classes. One's épyov, as what is most suitable for the individual and for his community, has to do with the achievement of the potentialities of one's nature.

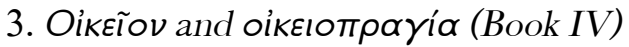

Now it's time to proceed to the main occurrence of «one's own», namely that concerning the very definition of justice through the idea of oikeı

${ }^{18}$ See the proverb of Theognis quoted by Aristotle in Nicomachean Ethics V, 1129b29: «in justice every excellence is comprehended» and the concluding lines of Nicomachean Ethics V 1, 1130a8-14. Nonetheless, according to ADKINs 1960, pp. 78-79, that doesn't mean that the equation between justice and virtue belonged to common sense morality.

${ }^{19}$ As rightly pointed out by SANTAS 2001 the «functional theory of the good» sketched in Book I is then used in the following books.

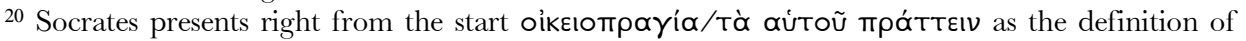
(social) justice: the first occurrences $(434 \mathrm{c} 8-10,435 \mathrm{~b} 4-5)$ take it as the definiens for the justice of the polis, further recalled at $441 \mathrm{~d} 8-10$. The social account is then articulated with the characterization of psychological justice at 441d12-e2: «we should also bear in mind, then, that in the case of each of one of us as well, the one in whom each of the elements does its own will be just and do his own [Ěka otos, ötou

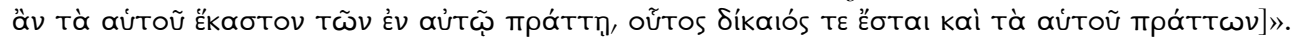
The various phrases expressing the «doing one's own» principle (the instrumental dative at $441 \mathrm{~d} 9$, the

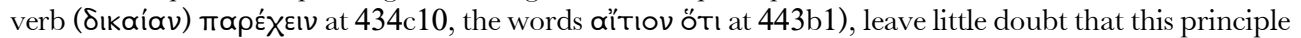
is the cause, or the necessary condition (435b4-5) for calling the being in question «just». Justice could then easily be paraphrased as the disposition or the state in which each of the constitutive elements does its own, these elements being those of the city or of the soul. Until the very final description of justice in the soul (443d1-3), Socrates sticks to the «doing one's own» formula. Let us notice, additionally, that 
quickly contextualizing this definition, I will turn to its meaning and implications in order to determine how it meets the challenge of the Republic and to find out what the specific dimension of the oikeiov is meant to bring in.

Having completed the construction of the just city, Socrates proceeds to locate the last virtue still missing: justice. Since every single class in the city has been provided with its specific excellence - wisdom to the rulers, courage to the guardians, with the little exception that temperance ( $\sigma \omega \varphi \rho \circ \sigma u ́ v \eta)$, the excellence of the producers, is also shared by the two other classes -, there is apparently no room left for a further virtue. Here comes Socrates' coup de théâtre: since every part is already endowed with an excellence, the only way to make sense of the presence of justice within the good city $(427 \mathrm{e} 8,434 \mathrm{e} 2)$ is to assume that it belongs to the whole: that's why Socrates and his companions were unable to locate it. As a definition, Socrates suggests that of tò

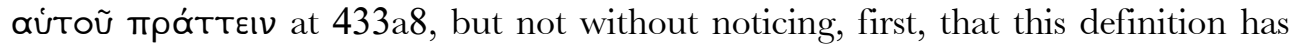
been at hand's reach from the beginning, i.e. from the very first step of the construction of the primary city, and secondly, that they have heard about it many times.

«What we laid down at the beginning when we were founding our city, as a general requirement - that, I think, or some form of that, is justice. And surely what we laid down and often repeated, if you remember, is that each person must perform one of the functions in the city, the one for which his nature was best adapted.

- Yes, we did say that.

- Moreover, we have heard many people say, and have often said ourselves, that justice is

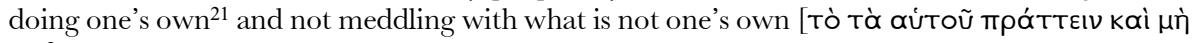

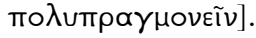

- Yes, we have.

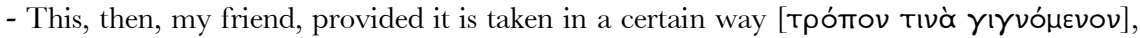
would seem to be justice - this doing one’s own [Tò Tơ aưToũ mpátTeıv]» (433a1-b4).

Each of these remarks deserves attention, as it should be whenever Socrates proceeds to a kind of mise-en-scene of his claims. Why does he argue that they have already told and been told about this account many times? It will not be the only time in the Republic that Socrates alludes to something supposedly already said or heard. Another - and famous - instance of some mysterious allusion is to be found in Book

Plotinus takes it to be the Platonic definition of justice on the basis of the Republic. Cf. Ennead. I 2 [19], 6-7 where he endeavours to make sense of the definitions of the virtues when applied to the Principle. He struggles especially with justice as oikeiopragia since this notion presupposes parts, of which the

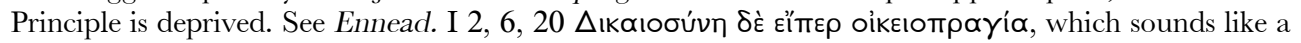
clear reminder of Rep. IV 434c.

${ }^{21}$ Following Vlastos 1973, p. 115, in keeping the literal and formulaic translation of tò aútoũ

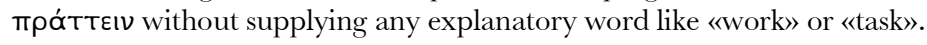


VI about the knowledge of the Good that Socrates enigmatically claims to have discussed many times $(504 \mathrm{e} 8,505 \mathrm{a} 3)$. In two key passages of the dialogue, therefore, Socrates uses a similar trick, prompting to pay attention to the forthcoming development.

Some commentators tend to deny without further ado any possible reference to the Republic or to any other of Plato's works ${ }^{22}$. But should the possibility of a back or external reference be dismissed so quickly? The cryptic allusion of Book IV does hint at something actually said in the Republic, in Book II (370a4), when the generative principle of the primary city, the principle of specialization, i.e. limitation to one function, is introduced for the very first time ${ }^{23}$. Furthermore, the phrases introducing this catchphrase in Book II and IV remarkably echo one another. The initial question at

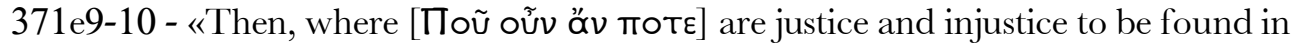
it?» - parallels narrowly the answer at $427 \mathrm{~d} 2-4$ - «Look yourself [...], to see where

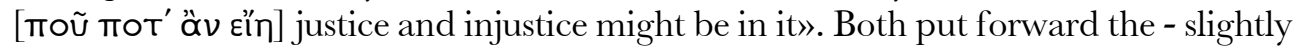
unexpected - question of the location of justice. This moũ question is especially noteworthy for one would rather expect the more familiar tí question about justice, as it was the case at the end of Book $\mathrm{I}^{24}$. Nonetheless, the problem is the following: «the principle of specialization is in full and easy view. It has been before us a long while. The difficulty is to see that it is justice» ${ }^{25}$.

Socrates furthermore claims that many others had also given this definition which is even more puzzling. Once again, it seems difficult to deny from the outset any possible reference to other works, since other instances of the same phrase are to

\footnotetext{
${ }^{22}$ See, among others, CORNFORD 1945, p. 124 and HAVELOCK 1978, p. 320.

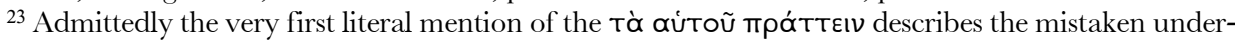
standing of «doing one's own», where everyone devotes himself exclusively to satisfying his needs without sharing any abilities or belongings with his fellow citizens. And the slightly mocking portrayal of the person torn between various activities, and running from one to another at 369e6-370a4, may remind

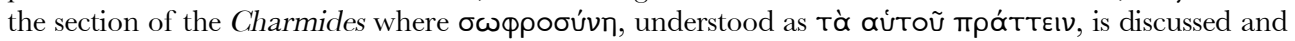

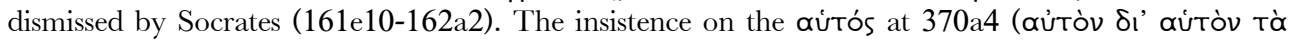

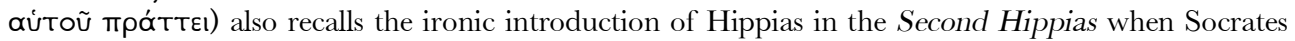

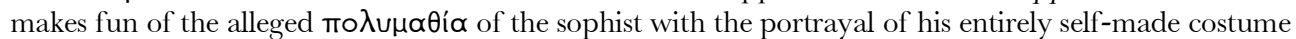
(368b-e) and the review of his other pretended skills. On this point, see DONOvAN 2003. But this selfcentered interpretation of the principle is soon opposed to the contribution of everyone's own work to the common use (369e2), which will turn out to be the correct understanding of the «doing one's own ", holding for the remainder of Books II and III (see II 374b9-c1; III 394e3-4; III 397e1-2; III 400e6; III

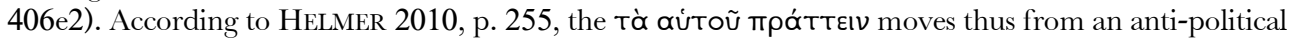
to a political meaning.

${ }^{24}$ See 354b4: «what justice is» [Tò Síkaıov ötı пот' Éotív].

${ }^{25}$ As summed up by BURNYEAT 2013, p. 214
} 
be found in Plato ${ }^{26}$. The tà aútoũ mpótreıv famously occurs in the Charmides as an attempt to define $\sigma \omega \varphi p \circ \sigma u ́ v \eta(161 b)$; it is also presented as a proverbial account

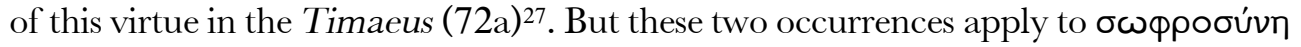
and not to justice. Admittedly the formula tà aútoũ mpótтยıı is commonly associ-

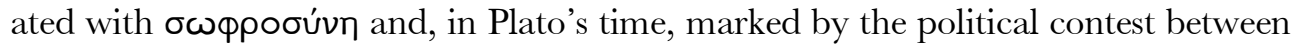
oligarchic and democratic factions, both are claimed to be distinctive of conservative aristocratic values ${ }^{28}$. Although it is true that $\sigma \omega \phi p o \sigma u ́ v \eta$ shares some features with justice, so that both virtues seem closely connected ${ }^{29}$, once again Socrates' claim turns

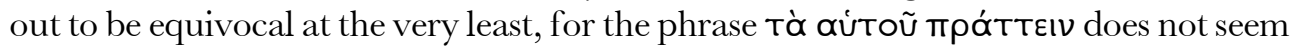
commonly supposed to be the account of justice ${ }^{30}$.

Some interpreters also suggest convincingly that the commonplace formula for justice that Socrates has actually in mind is tơ aútoũ éX $\chi V^{31}$. This wording, close to his own one, constitutes indeed the traditional concept of justice based on property ${ }^{32}$. Socrates would then proceed to an unnoticed expansion from the traditional sense (having one's own, i.e. possessing) to a new definition (doing one's own, i.e. acting) ${ }^{33}$ - and that would explain why Socrates' interlocutors are supposedly acquainted with

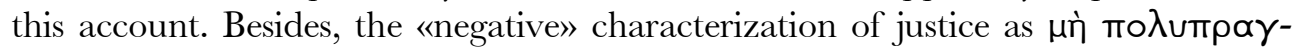

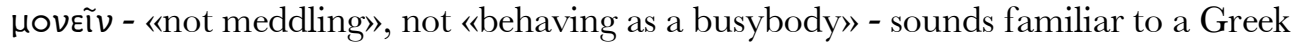

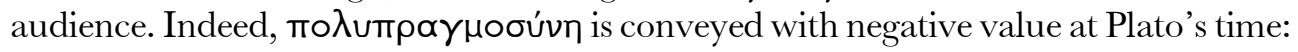
it is the political equivalent of the contiguous, but less politically committed, ü $\beta$ pı or

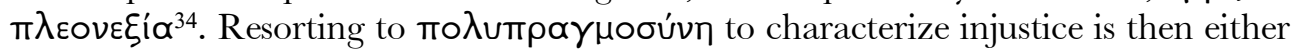

\footnotetext{
${ }^{26}$ Besides the many occurrences in the Republic, the phrase appears in the Apology (33a) and in the Gorgias (526c), those two passages describing the philosophical life.

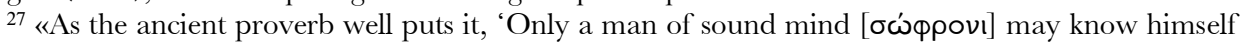

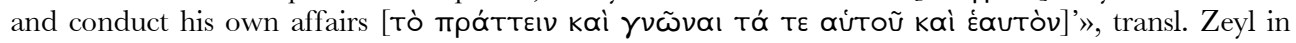
COOPER 1997.

${ }^{28}$ See e.g. Guthrie 1975, pp. 166-167, SCHMID 1998, pp. 4-5, NORTH 1966, pp. 111-112. I am thankful to the anonymous referee for bringing this political context to my attention.

${ }^{29}$ Several clues point to their mutual overlap. Both are virtues applying to the whole city (see 432a14 for temperance, $433 \mathrm{~d} 1-5$ for justice); both are defined in terms of harmony (see 430e4, 431e 8 for temperance, 443d5, 443e 2 for justice). Rowe 1979 addresses the issue of the unclear distinction, if there is any, between the two virtues in the Republic.

${ }^{30}$ In Alcibiades (127b f.), the authenticity of which is controversial, the formula occurs within an

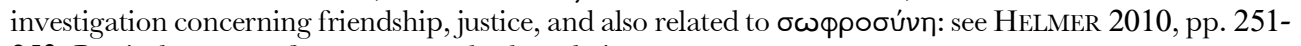
253. But it does not refer to commonly shared views.

${ }^{31}$ See Gutglueck 1988 and SchütrumpF 1996.

${ }^{32}$ See SCHÜTRUMPF 1996, pp. 51-54.

33 According to Gutglueck 1988, p. 37.

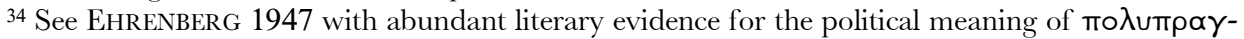

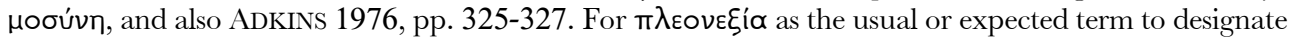

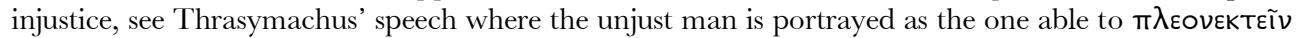
on a large scale (344a1), and Aristotle who turns to $\pi \lambda \varepsilon \circ \varepsilon_{\varepsilon} \xi$ ía $^{\prime}$ as the contrary of justice for delimiting
} 
meant to stress the political dimension of this other contrary of justice, or it is intended to draw on its linguistic root referring to action, as we shall see a bit later. In any case there are some reasons for not ignoring Socrates' claim that this account has already been heard.

Nonetheless, the motto of «doing one's own» is submitted to a wide-ranging re-

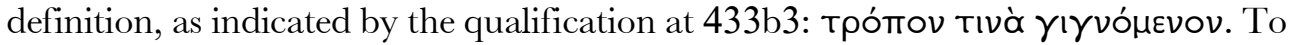
what extent does this Platonic understanding modify the ordinary meaning of the

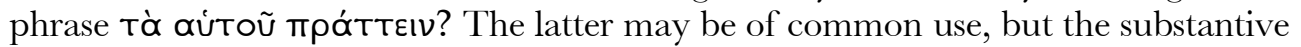
coined from it, oikeı significant amendment that the former catchphrase will undergo. Given the organizing principles of the ideal political community that have been laid down, it is now clear that the oikeĩov in question is not just a contingent matter, but has to be found in the function for which one is devised by nature. As the construction of the first city in Book II demonstrated, doing one's own does not amount to minding one's own business in some self-centered way but rather to accomplishing the task corresponding to one's capacities. Nature (фúøı) is indeed the basis for the ascription of the right function to each person or class in the city, as Socrates emphatically recalls it at $433 \mathrm{a}^{36}$. This natural basis has been supplemented and strengthened at the end of Book III with the «noble lie» of autochthony and the tale of three races (414b-415d).

Without putting too much weight on the term oikeıompayia, let us notice that this abstract neologism, which occurs only once at $434 \mathrm{c} 8$, taken in a strictly literal sense, narrowly matches the account of épyov launched in Book I. Performing one's

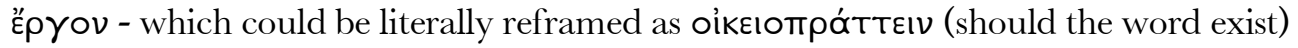
- would not be possible without the proper virtue (see 353b14-c2, c6-7, quoted earlier). As mentioned earlier, the introduction of the épyov resulted in yoking the notion of virtue and that of the nature of the subject together. If this view is correct, the description of justice as oikeı end of Book I, by vindicating what Socrates' refutation of Thrasymachus had simply taken for granted, namely the status of justice as overall virtue. This feature can now be understood on a deeper level. The full demonstration that justice is indeed the virtue of the whole soul and then a synonym for virtue in general requires securing the

the scope of particular justice contrasted with other virtues in $N E$ V 2 (1129a32, b1, b7, b9, b10): $\pi \lambda \varepsilon \circ \varepsilon_{\varepsilon} \xi^{\prime} \alpha$ is the vice corresponding to the kind of unjust acts that cannot be referred to any other vicious motive like intemperance or cowardice (1130a16-32).

${ }^{35}$ According to the TLG, no occurrence prior to that of the Republic is attested. Another, and quite

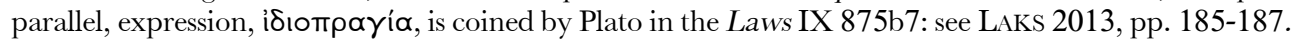

36 433a6: «the one <function> for which his nature was best adapted [Eis ô aútoũ ì qúoıs

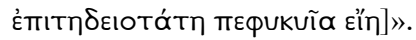


isomorphic structure of the city and the soul: the first political definition, the eidolon ${ }^{37}$ of justice illustrated by the «one man, one job» principle, has to be extended to the soul that turns out to be tripartite ${ }^{38}$. The isomorphism between city and soul is crucial

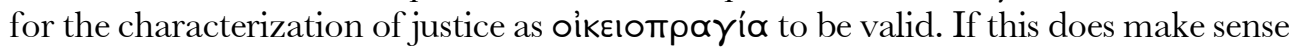
for a being made of parts, as it is the case with the city, in which the «doing one's own» principle allows its constitutive elements to cohere and prevents the compounded from falling apart, it seems to be more challenging to stick to it on the scale of a being that is already seemingly one, i.e. the human being. Having proved that the soul is endowed with parts each of which is devoted to a specific function or activity, Socrates will then be entitled to apply to the soul his previous accounts of the virtues, including that of justice.

In the compound oikeı omparia, both elements are important and concur to single out justice. One important feature lies in the focus on agency, the capacity of action. The focus on action is sensible, in the supposedly traditional conception of tà aútoũ

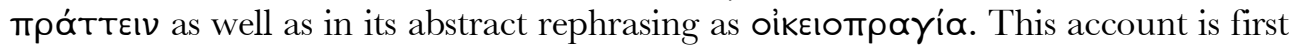
supported by the exemplifications of justice in the various actions that common morality would not allow any just person to perform (stealing, temple-robbing, betraying, breaking one's word, committing adultery, neglecting one's familial and religious duties...) at 442e-443b5: all these actions can be interpreted as doing one's own in the sense of keeping hands off what belongs to others and of accomplishing one's duties ${ }^{39}$. But beyond the level of these external instantiations of justice, one ought to under-

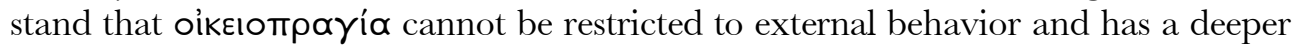
meaning at the level of the soul itself. Therefore, the task is now to make good sense of the notion of oikeı mparia and of the focus on action when it comes to the soul. That's why Socrates stipulates that justice lies in a person's inner activity $(443 \mathrm{c} 9 \mathrm{ff}$.):

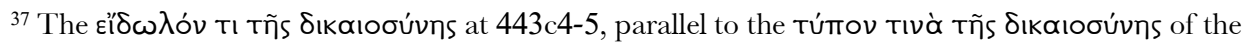

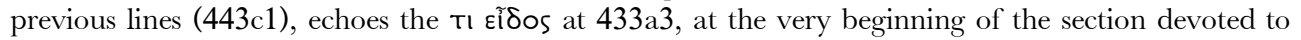
justice. eí $\delta \omega \lambda$ ov, I take it, does not necessarily have the negative sense of a phantom here, but might rather be understood as an image, i.e. a concrete representation of some abstract or invisible entity (see Theaetetus 208c5, Politicus 286a1). Contrary to ADAM 1963, I, p. 262 note ad 443Bff., I don't take the civic or politic justice to be, as a shadow or a copy, less valuable than psychic justice. The isomorphic relationship between soul and city does not imply any hierarchy between them, only a variation of scale (see 435a5-b2). See also BuRnYEAT 2013, p. 230, «individual justice and social justice are both cause and effect of each other».

38 See 435a-441c. Within the limits of this paper, I cannot discuss the details of this crucial part of the argument that I shall only take for granted. Plato's Greek does not always use the word «part» when referring to the several subjects of various and possibly conflicting impulses but he clearly opposes them to the «soul as a whole» at 436b2. The term $\mu$ épos is however used at 442b10, c5 when Socrates entrusts two of the parts of the soul with their own virtue. See Lorenz 2005, p. 20.

39 Though framed negatively, as abstaining from wrongdoing, rather than positively, these instantiations match common representations of just behavior: see COOPER 2004, p. 258. 
«Uustice is, it seems, something of this sort. Yet it is not concerned with someone's doing his

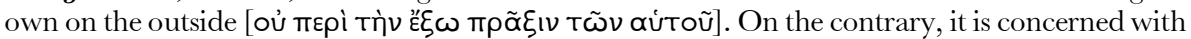

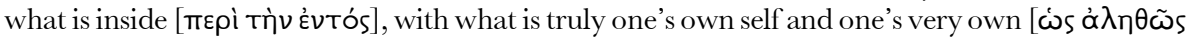

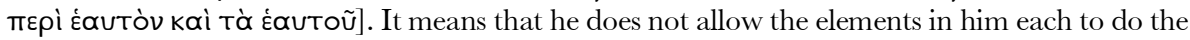

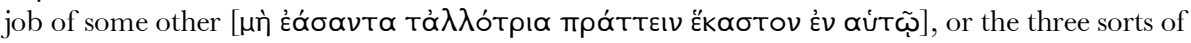

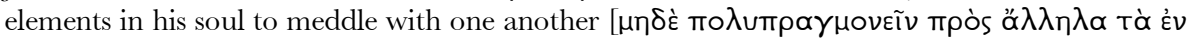

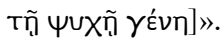

This insistence aims at strengthening the isomorphism with the city ${ }^{40}$. In a city, oikelompayía means for each of its parts to do its job, what is responsible for the harmony of the whole. For an individual, it cannot be simply understood as sticking to his social function and accomplishing his social duties. Otherwise the parallel would not hold. The very same plurality is to be found within the single soul, each of which constitutive parts restricts itself to its functions and objects, and does not try to overstep them. Justice is nothing other than some inward activity by which each component of one's being sticks to its assigned task.

This focus on action may thereby help distinguishing justice from temperance. While temperance in Republic IV is defined in terms of true belief ${ }^{41}$, as an assent to the right order and hierarchy between what ought to rule and what ought to be ruled (433c6-8), the characterization of justice in terms of oikeı straightforwardly to action. This focus on action may also explain why Socrates chose

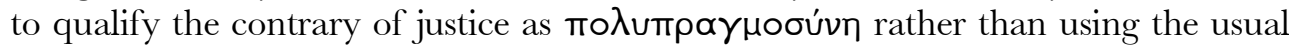
$\pi \lambda \varepsilon \circ v_{\varepsilon} \xi i \alpha$. Besides the abovementioned obvious political connotation of the former, the wording itself refers to action, so that the term marks out the very antithesis of

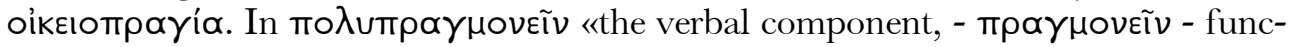

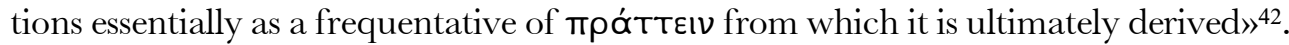

This focus on action was already underlying the first book. It is implied by the very first discussion with Polemarchus, where Socrates wonders «in what action ( $\pi \rho \tilde{\alpha} \xi 15)$ or with respect to what work (" $p \gamma o v$ ), then, is the just man the one most able to help friends and harm enemies» (332e3-4). The definition of justice now achieved may account for the fact that Polemarchus was unable to suggest any specific action for which the possession of justice would be specifically responsible and beneficial. Indeed, it turns out that justice does not consist in any specific external action, as we have just seen, but in a certain and general way of acting by governing each of our

\footnotetext{
40 A detailed account of the parallel procedures for defining justice within the frame of the city-soul analogy is given by BURNYEAT 2013.

${ }^{41}$ The definition of courage likewise entails a cognitive element, as true belief about what is to be feared or not, while wisdom, unsurprisingly, is expressed in terms of knowledge (see $428 \mathrm{~b} 6 \mathrm{ff}$.).

${ }^{42}$ As pointed out by GUTGLUECK 1988, p. 36.
} 
actions insofar as it rules over our whole soul. More importantly, the argument of the «gang of thieves» in Book I has already suggested that the effect of justice is to make an action possible. Socrates had indeed pushed Thrasymachus to admit that injustice, implying disorder and revolt within any whole constituted by several elements, would finally make this whole unable to act, because this lack of agreement and cooperation results in internal chaos (351d-352a). In Book IV 444b Socrates significantly uses the same language as in Book I, the lexical field of $\sigma$ tó $\sigma 1 s^{43}$, to describe the effects of injustice in the soul. In the discussion with Thrasymachus, the argument was then extended without further justification to the individual, whose compounded nature remained anything but warranted at that point of the dialogue (351e6). The analysis of the soul provided in Book IV enables us to give account of this argument and to make full sense of the view that injustice makes one incapable of genuine action, powerless rather than powerful ${ }^{44}$. Even the individual proves to be complex, rather than simple: his soul turns out to involve three parts whose harmony is obtained over and against dispersal and disagreement.

If I am right in pinpointing this focus on action attendant to the definition of justice $^{45}$, this idea might have further connection with the structure and the aim of the whole argument of the Republic. Let us recall that Socrates has to take up the challenge that consists in showing that a just life is a happy one (352d1-6). Let us also bear

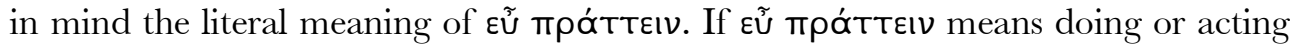
well, and if justice, as the virtue of the whole soul, consists specifically in acting, then,

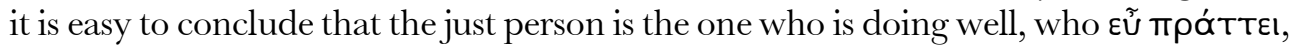

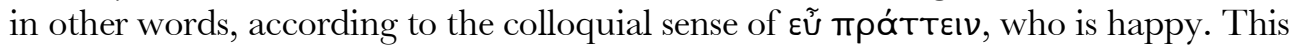
is of course not the end of the argument, which will go on until the end of Book IX, but it may be a subtle introduction of it. If one bears in mind the very end of Book I and its quite abrupt ending of the discussion, Book IV seems to provide a much more

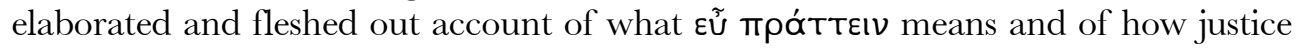
and happiness could be closely interwoven within it.

«Equally, the perfect performance of its function is evidently the eu prattein, the 'faring well', the eudaimonia of each element, for this performance give complete satisfaction with no regrets. Dikaiosyne is the condition in which each of the elements is performing its function perfectly, is displaying its aretē, excellence, is agathos, a good specimen of its kind, eu prattei, is in a state of

43 The vocabulary at 444b1, 444b3 echoes narrowly that of 351d3, e2, 352a2, a6. Later on, at

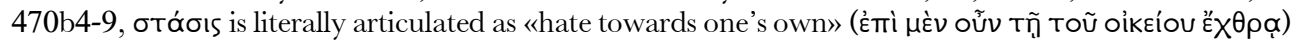

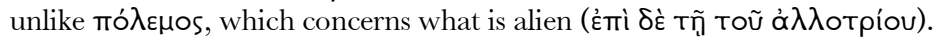

${ }^{44} \mathrm{~A}$ further hint that Book IV meets the initial challenges of Book I is that the conclusion reached at IV 443e4-444a2, showing that justice is a goodness implying wisdom [бoథíav], a injustice a vice involving ignorance [å $\mu \alpha \theta \dot{\alpha} \alpha v]$, takes over the very terms of Socrates' interrogation at I 354b6.

${ }^{45}$ See also Gutglueck 1988, p. 37-39, for further evidence. 
eudaimonia. Thus dikaiosynē is an aretē and an essential condition of eudaimonia; which is what Plato set out to prove» ${ }^{46}$.

To meet Thrasymachus' challenge, Socrates' account of justice ultimately has to show that the action performed by a just soul actually benefits the agent and his own interests instead of alienating him. Here is the point marked out by the oikeĩov in the

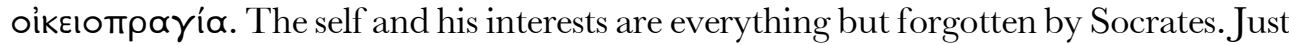
after specifying that justice has to do with inward, rather than outward action, he

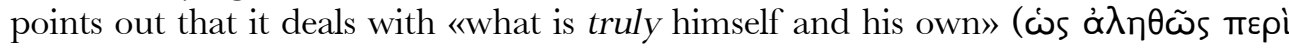

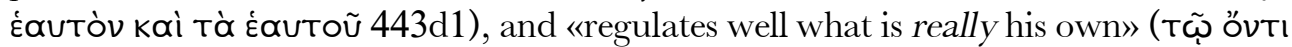
Tà oikeĩ $\varepsilon \cup \tilde{~} \theta \varepsilon ́ \mu \varepsilon v o v ~ 443 \mathrm{~d} 3-4)$. The focus on the self is rather striking in this account of justice but these modifying qualifications make it clear that the self and his own are very different from the ordinary meaning of the terms from which we started in Book I. The former is nothing but the soul, far away from that social self, longing for power, honors and the social considerations that a cunning injustice was supposed to provide us with. The latter is nothing but the best capacities of the soul, expressing its very nature, far away from any material goods, family and property that unjust acts were supposed to secure. This is all the more obvious since at least two of the three classes in question, the guardians and the rulers, have no property (cf. 416c). What tò oikeĩ $\alpha$ means, thus, cannot refer to any kind of possession anymore. Finding and arranging what is really his own, namely the parts of his soul ${ }^{47}$, enables the individual to become one and oneself, from the many he used to be (443e1-2). Lines 443d-e do not only intend to parallel the effect of justice at the political level of a community that is by nature made of several and separate elements. They also deliver some truth about what it takes for a person to become one, to unify him- or herself. In this process, to locate what is one's own is essential, given that this «own» cannot consist any longer in belongings or material items. That justice promotes the genuine self and one's own has become clear provided this wide-ranging transformation of our preconceptions.

The description of injustice might support this view: facing Adeimantus' objection that the way of life he assigned to the guardians is likely to make unhappy the very best men, those arguably the most entitled to satisfy their desires, Socrates replies by depicting a situation matching narrowly what is going to be designated as

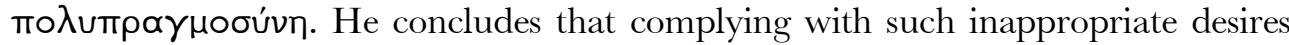
would «make them something other than guardians» (420d). That is what would

\footnotetext{
46 As ADKINs 1960, p. 286 insightfully comments.

${ }^{47}$ That the soul, especially the intellect, is one's own more than anything else is formulated in an incidental remark pointing out that for the souls, the pain resulting from the intellectual effort, compared with that of physical effort, is «more their own [oikelótepos], being peculiar to them and not shared with the body» (535b6-9). See also Laws V 726a2 ff., commented by LAKs 2013, pp. 186-187: «Of all the

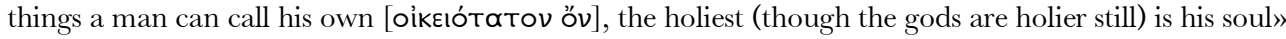
(transl. Saunders in COOPER 1997).
} 
happen if they let one part of themselves, in this case the appetitive part, take control over themselves, if they err about what is their own, forgetting that it does not lie in belongings, but rather ultimately in an activity. For doing one's own consists in doing what one should do, given what one's nature is. The function to perform, provided it is appropriate to one's nature, expresses what one is. This injustice internal to their soul, preventing performance of their function within the city, would then affect what they are. In other words, it would alter their nature, and such indulgence, once extended to the whole city, would result in the fact that «a farmer wouldn't be a farmer, nor a potter a potter, nor would any of the others from which a city is constituted remain true to type» (421a). The inordinate growth of desires that are irrelevant to one's function would turn upside down the internal structure of the city by preventing each part of it from doing its task, altering the very nature of each of these parts and thereby dooming the city. This imaginary scenario provides us with a description of

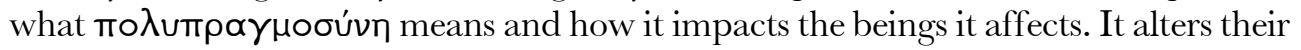
identity, what they are, since they are not able to do their own anymore.

If this reading of the oikeı

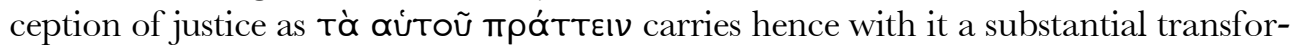
mation. It is not just a matter of restricting oneself to one's belongings or business without trying to take advantage of other people, i.e. of avoiding $\pi \lambda \varepsilon \circ v \varepsilon \xi i \alpha$. Rather, it seems that the two parts of the compound oikeıomparía deserve attention and that their scope goes much further than expected at first sight. Justice is indeed the virtue that expresses itself in action. Because such an action is appropriate and peculiar to one's nature, by doing one's own, one becomes one and oneself. Contrary to what Thrasymachus emphatically claimed, justice is not what severs us from our own. It rather consists in doing one's own, in finding and realizing it. As a result, once the nature of this «own» has been understood, and once the tentative and sketch-like argument from the end of Book I has been supplemented with the developments of Book IV, one is fully in position to understand that justice, as achieving one's own, definitely promotes one's happiness.

\section{Conclusions}

This paper intended to give a quick sketch of the intensely discussed account of justice in the Republic through the peculiar focus on the oikeĩov. Using the notion as a guiding thread throughout the vast frame of the Republic elicits some Platonic concerns, otherwise likely to be overlooked. First, it shows how Socrates' account of justice meets point by point Thrasymachus' challenge by attempting to fill the gap that the latter had diagnosed between the practice of justice and the pursuit of one's own good. Then, it illuminates the progress of the discussion, by gradually elaborating the concept of justice as a virtue, unfolding by the same token its connection to happiness. Following the tracks of the oikeĩov brings out how some tentative answers from Book 
I come to completion and full sense through the later developments of Books II to IV. Ultimately, focusing on the role played by one's own in the overall case for justice makes it clear how the human being can appropriate the good. Indeed, Platonic justice is the virtue of the whole - city or soul: it consists in one's own activity and proves able to unify this whole through the very same activity. It is thus able to suggest how the good can belong to us. The good is not only to be found in a distant Form, possibly out of reach, as Aristotle's criticism will not fail to point out in Nicomachean Ethics I 6. It also consists in one's activity, in the achievement of one's nature. This is precisely what makes the good oikeĩov, proper or appropriate to us - a view that would not be that alien to Aristotle himself. Reading through the Republic from the perspective of one's own, by paying attention to the way it intervenes and interacts with other ethical concepts of the work, makes it clear how Plato can face the concern about the distant character of his conception of the good and the attendant difficulty to relate it to what one would expect the human good to consist in. Once having located one's own in one's activity instead of confusing it with one's belongings, each of us should be able to understand a bit more clearly how and why justice, as dealing with one's own, will eventually make its possessor happy ${ }^{48}$.

\section{Bibliography}

Adam, J. (1963), The Republic of Plato, I-II, Cambridge.

Adkins, A. (1960), Merit and responsibility; a study in Greek values, Oxford.

Adkins, A. (1976), «Polupragmosunē and 'Minding One's Own Business': A Study in Greek Social and Political Values», Classical Philology, LXXI 4, 301-327.

Blundell, M. (1991), Helping friends and harming enemies: a study in Sophocles and Greek ethics, Cambridge.

Burnyeat, M. (2004), «Fathers and sons in Plato's Republic and Philebus», Classical Quarterly, LIV 1, 80-87.

Burnyeat, M. (2013), «Justice writ large and small in Republic 4», in V. Harte, M. Lane (eds.), Politeia in Greek and Roman Philosophy, Cambridge, 212-230.

Cooper, J. (2004), «Two Theories of Justice», in Knowledge, Nature and the Good, Princeton, 247-269.

Cooper, J. (ed.) (1997), Plato, Complete Works, Indianapolis.

Cornford, F. (1945), The Republic of Plato, Oxford.

Donovan, B. (2003), «The do-it-yourselfer in Plato's Republic», American Journal of Philology, CXXIV 1, 1-18.

48 I would like to thank M. Crubellier, B. Morison, and C. Rapp for their helpful comments on earlier drafts of this paper. I am also grateful to the anonymous referees of «ПНГН/FONS» for their critical remarks. 
Ehrenberg, V. (1947), «Polypragmosyne: A Study in Greek Politics», The Journal of Hellenic Studies, LXVII, 46-67.

Gutglueck, J. (1988), «From pleonexia to polupragmosunē. A conflation of possession and action in Plato's Republic 349b-350c», American Journal of Philology, CIX 1, 20-39.

Guthrie, W. (1975), A History of Greek Philosophy, IV. Plato, the man and his dialogues: earlier period, Cambridge.

Havelock, E. (1979), The Greek concept of justice. From Its Shadow in Homer to Its Substance in Plato, Cambridge (MA)-London.

Helmer, E. (2010), La part du bronze. Platon et l'économie, Paris.

Laks, A. (2013), «Private matters in Plato's Laws», in C. Horn (hrsg.), Platon. Gesetze-Nomoi, Berlin, 165-188.

Lorenz, K. (2005), The brute within, Oxford.

North, H. (1966), Sophrosyne: self-knowledge and self-restraint in Greek literature, Ithaca (NY).

Reeve, C. (ed.) (2004), Plato, Republic, Indianapolis.

Ross, D. (ed.) (1955), Aristotelis Fragmenta Selecta, Oxford.

Rowe, C. (1979), «Justice and temperance in Republic IV», in G. Bowersock, W. Burkert, M. Putnam (eds.), Arktouros. Hellenic Studies presented to Bernard M.W. Knox, Berlin-New York, 336-344.

Santas, G. (2001), Goodness and Justice, Plato, Aristotle and the Moderns, Oxford.

Schmid, W. (1998), Plato's Charmides and the Socratic Ideal of Rationality, Albany (NY).

Schtrütrumpf, E. (1996), «The definition of justice in Plato's Republic», in R. Faber, B. Seidensticker (eds.), Worte, Bilder, Töne. Studien zur Antike und Antikerezeption: Bernhard Kytzler zu ehren, Würzburg, 51-58.

Vlastos, G. (1968), «The Argument in the Republic that 'Justice Pays'», The Journal of Philosophy, LXV 21, 665-674.

Vlastos, G. (1973), «Justice and Happiness in the Republic», in Platonic Studies, Princeton, 111-139.

Waterlow, S. (1972-3), «The Good of Others in Plato's Republic», Proceedings of the Aristotelian Society, LXXIII, 19-36. 